\title{
ANALysis AND DePENDABILITy OF Production PROCESSES FOR THE AUTOMOTIVE INDUSTRY
}

\author{
Katerina Bicova, Lukas Bebr
}
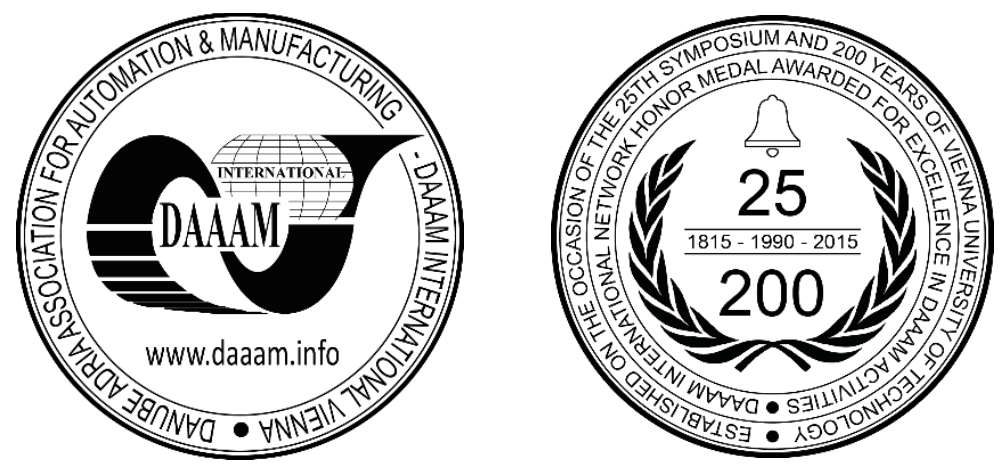

This Publication has to be referred as: Bicova, K[aterina] \& Bebr, L[ukas] (2018). Analysis and Dependability of Production Processes for the Automotive Industry, Proceedings of the 29th DAAAM International Symposium, pp.0416-0420, B. Katalinic (Ed.), Published by DAAAM International, ISBN 978-3-902734-20-4, ISSN 1726-9679, Vienna, Austria

DOI: $10.2507 / 29$ th.daaam.proceedings.061

\begin{abstract}
With the increasing demand for product accuracy and quality of all services it is getting pivotal to monitor and analyse key processes. The submitted paper points out the question of monitoring and evaluating the manufacturing processes in the automotive industry. Its main objective is how to choose suitable indicators for monitoring and subsequent analysis. This choice must retain their maximum predicative ability about the actual and dependability properties of given process.
\end{abstract}

Keywords: indicator; IATF 16949; evaluation of process; dependability

\section{Introduction}

In connection with the application of the ISO 9000 series requirements and in particular the mandatory IATF 16949 requirements for the automotive quality management systems, the organizations must address the issue of supervising the measurement and monitoring processes.

For production processes, this requirement is required to verify the suitability of processes and to provide additional input for process control, including studies of special characteristics. [1] These are then important parameters that ensure the required capability and reliability of the production process. Reliability of business processes is a prerequisite for the implementation of high-quality production in the allotted time, which indicates the reliability of supplies to the customer, which, jointly with quality and price, are the criterions of competitiveness and hence the criterion of continuous business success.

Monitoring under IATF 16949 means a set of activities aimed at obtaining information relevant to the management system. The control system can usually be represented by the following diagram (Fig. 1). 


\section{DISTRACTION FACTOR}

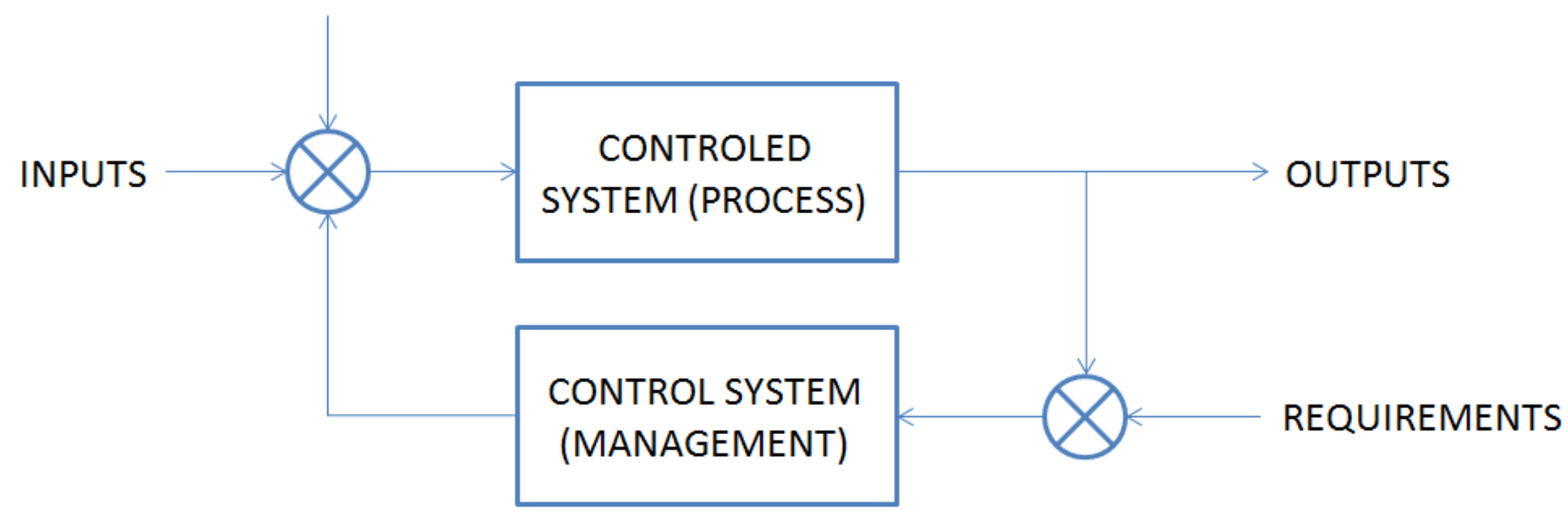

Fig. 1. The general model of management system [2]

In practice, it is to be expected that executives and process owners have to consider the need for process measurement and analysis, however also to reckon with added work intensity and increased need for resources connected with that. In particular, the requirements for details, frequency and accuracy of the measurement significantly affect the costs that process analysis requires. It follows, that the key area of creating methodologies for monitoring and measuring processes in quality management systems is always the choice and specification of suitable indicators that should be monitored and objectively characterize the process. [3] The aim is therefore to contribute to optimizing and streamlining the overall approach to process monitoring.

\section{Choice of evaluation indicators}

After a detailed description of the process, a brainstorming analysis was carried out to select a range of the most appropriate indicators for process monitoring and analysis, so that their application didn't imply an ineffective increase in labour input, but at the same time maintained maximal information output about the true characteristics of the process. Selected tools and parameters to evaluate the production process are as follows:

- Histogram

- Control charts

- Process capability

- $\quad$ Relative frequency of nonconformities / average scrap

- Cause and effect diagram

- Dependability

Based on the requirements of IATF 16949 for quality management systems in automotive production the organisation must stipulate suitable usage of statistical methods, which have to be included in the risk analysis, inspection plans, working and inspection instructions and control.

Also basic statistical concepts such as variability, regulation (stability), process capability and its re-regulation must be presented in such a manner, that these are understood and used correctly throughout the organization. [1]

In view of this fact capability was chosen as the first indicator for the assessment of the production process. However, the determination of capability is conditioned by the stability of the process being analyzed. This is verified by help of control charts. Therefore control charts are selected as the other tool for process analysis. The control charts reflect the histogram that represents the data distribution. Besides that, the histogram assembling is a graphic method for verifying normality but serves only as an estimate. For a more accurate determination, the Q-Q graph can be used.

To assess variability and impact on the manufacturing process, Ishikawa's diagram most frequently used tool is also referred to as: Cause and effect diagram. Another way of evaluating the process is to determine the Relative Frequency of Nonconformities / Average scrap rate, which is one of the typical management parameters for the assessment of production. A new view of the process evaluation is to determine their dependability. Dependability is a sign of process quality as well as product quality. The dependability of the process also reflects in some way its stability, and its evaluation should therefore become an important element in the assessment of its capability. [4]

\section{Histogram}

The histogram shows the data distribution and is a graphic method for verifying (estimating) normality. It is important to have sufficient amount of data available. The minimum number of values for histogram compilation is about 25 - 30, and the number of classes is from 7 to 20 in order to get a clear and distinct shape. 


\section{Control charts}

Control charts allow for long-term monitoring of the stability of the process, variability of a parameter caused by random fluctuations, or other causes. Usage is possible where the parameter is tracked over time. Before the construction of the control charts, the following (for the production process) [5,8] must be verified and known:

I. Presumption of normal probability distribution

II. A good stability test requires 20 or more subgroups containing about 100 or more individual values

III. Data must be chronologically organized, it is necessary to know the sequence of individual values - according to the time of production.

If the production time of each piece is unknown, data can be sorted, for example, by batches for which production time is known. In the case of control charts, the production time is important due to the subsequent reaction to variability, points outside the control limits or other trends in the diagram. If production time (or at least shift times, operators, tools, etc.) is not known, subsequent identification of causes is impossible.

IV. Determination of control intervals, for what period the control charts will be generated. Of course, it depends on the nature of the production and the number of pieces produced. For a sufficient amount of data, for example, a day or shift is recommended, where it is possible to respond more quickly to any variability. Over a long period of time, feedback is prolonged, together with the possibility of correcting or increasing the number of non-conformances.

\section{Capability}

The qualitative capability indicator of the process expresses the ability to permanently achieve predefined quality criteria. Determination of capability assumes confirmation of process stability, confirming the record of assembled control charts.

The table below shows each index of capability depending on Sigma - process level. Process capability is spoken from $\mathrm{Cp}=1.33$, ie from level $4 \sigma$.

For normal distribution, the value is usually 1.33. The value of 1.33 apparently appears to be an established rule, but for the automotive industry this value is no longer sufficient. For this area, this value is considerably increasing, which is a more strict eligibility criterion. Therefore, a value of 1.67 is selected for this case. From the manufacturer's point of view, the criterion is to increase the tightening criterion.[6]

\section{Relative frequency of nonconformities / average scrap}

It is one of the typical managerial parameters for the assessment of production. These indicators can be determined without prior checking of normality or process stability by using control charts. These are indicators for internal needs (for example, prior to a control-expedition that is for the company's internal needs), but if it is not possible to determine capability for some reasons, it is a sufficient conclusion.

Whether the values are satisfactory is explained in the following figure (Fig. 2), where the 6 Sigma rule is shown, indicating ppm for each band.

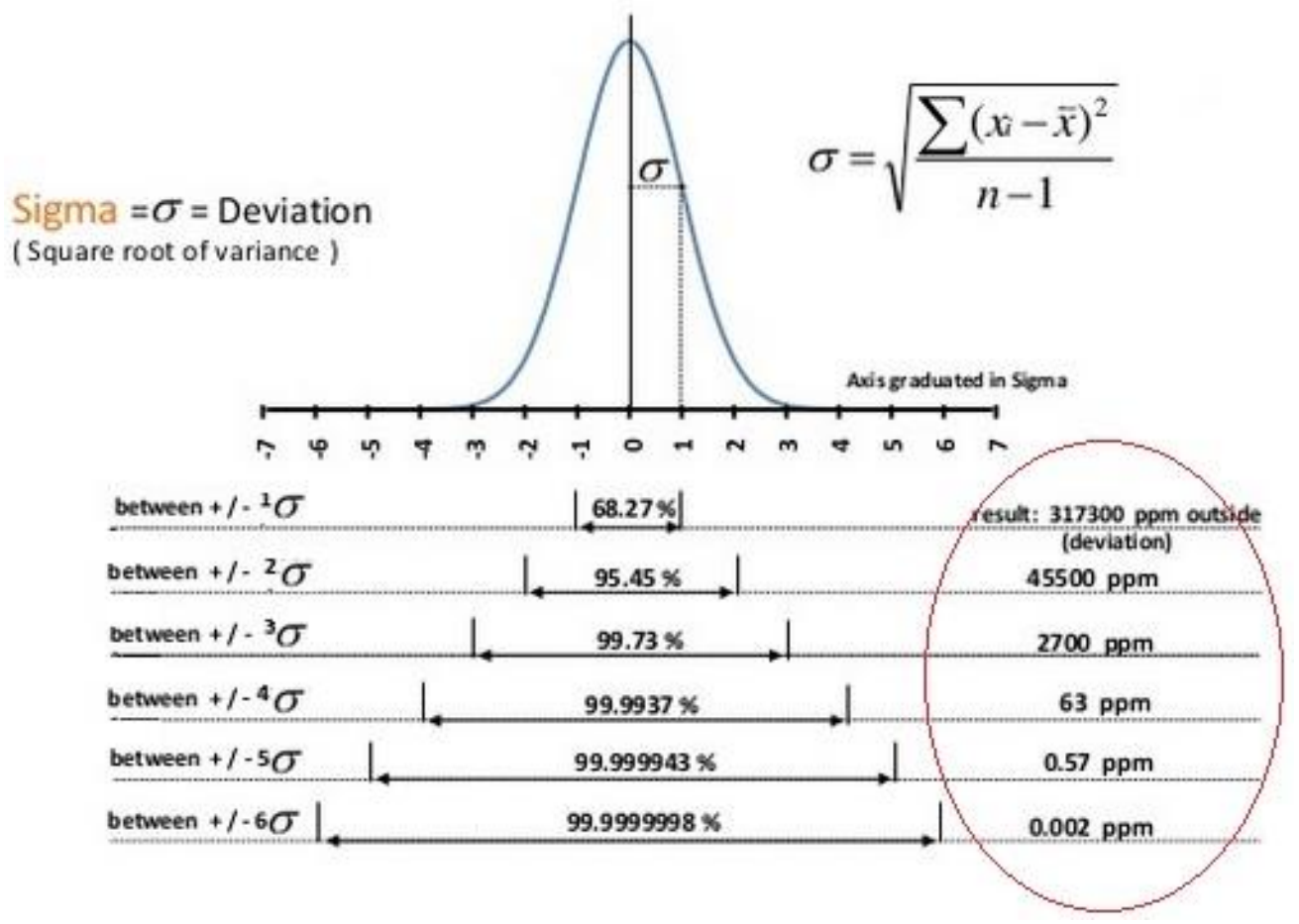

Fig. 2. Six sigma as a Metric [7] 


\section{The cause and effect diagram}

The cause and effect diagram serves to determine the causes of variability and impacts on the manufacturing process. This tool is suitable for determining causes for example trends, points out of bounds, or other variability in control charts. When according to production time, how the component was manufactured, how, under what conditions, whether there was any change such as tool change, calibration, service, etc.

For application of this tool a team is needed, which is diverse in terms of both profession and organizational position. Different views $=$ Different opinions and hence a greater likelihood of faster finding the cause of the nonconformities.

By focusing on the manufacturing process, it is a tool that can identify weaknesses in the process and thus identify possible risks, predict where an error or a problem might occur. [5]

\section{Dependability}

Another equally important way to evaluate processes is to evaluate dependability. Dependability in a process can't be determined strictly or analogically by examining systems and processes and monitoring them. In determining the dependability of the process, we first have to divide the process into parts or manifestations that we need to examine and monitor.

These manifestations can best ascertained by using a fish bone diagram, or using a cause and effect analysis. Subsequently, it is necessary to determine the effects on the process. Whether they are negative or positive and to analyze possible local or systemic consequences.

It is necessary to start from the basic idea of the process, what its functional features are and how to ensure its functionality for the time needed to create the desired output from the process. The process dependability indicator expresses the stability of the input to output transformations. Thus, using certain statistical methods, such as the Reliability Block Diagram RBD, we can also express the likelihood that under predefined conditions there will be a realization of this transformation in given time period.

\section{Evaluation}

Based on the analysis of the selected process, it is possible to state according to the results of the applied evaluation methods and the values of the selected indicators whether the process is eligible or ineligible or whether the evaluated indicators meet the assumptions and do not exceed the given limit values.

If the analysis indicates an incapable process, the indicators are outside the set boundaries, or the process course is not as expected, these facts need to be addressed by corrective action. The basis is to find the true cause of the problem, for example, using the Cause and Effect Diagram.

The organization will then have to develop and implement a corrective action plan specifying specific measures, timelines and responsibilities to ensure a stable and statistically competent process.[1]

In addition to setting preventative measures and suggestions for an appropriate way to monitor the process for the next period, IATF 16949 requires procedures for continuous improvement. The organization must include in these procedures a plan of measures to improve the manufacturing process with emphasis on reducing process variability and loss or risk analysis. Continuous improvement is only implemented when production processes are statistically controlled and stable, or when product characteristics are predictable and meet customer requirements.[1]

\section{Conclusion}

Overall and continuous process monitoring is an essential part of their management to ensure greater competitiveness. The key to identifying the appropriate features to be monitored and managed is to identify the complete product, detailed knowledge of the process, and the identification of critical quality marks.

Process dependability is a nonstandard view of business process management issues, but its importance is steadily increasing, and with increasing pressure on quality, it will increasingly be preferred as part of the tools needed to manage processes as such.

That is why we must continue to address this issue. The aim of the next research is to propose a methodology for monitoring processes based only on reliability indicators, while verifying their ability to demonstrate the actual characteristics and reliability of the process compared to "classical" indicators.

Whatever indicators the process owners choose to measure and monitor processes, they should realize that measurement and monitoring alone is not enough. Data obtained from these measurements should be systematically analyzed using appropriate statistical methods to identify trends and reveal opportunities for further improvement. Once the continuous improvement processes are carried out, it will prove the effectiveness of measurement and monitoring.

\section{Acknowledgments}

This article was created under the project SGS-2016-005: Research and development for innovations in the field of mechanical engineering technology - machining technology. 


\section{References}

[1] Norma pro systém managementu kvality v automobilovém průmyslu IATF 16949:2016. Praha : ČSJ, 2016.

[2] Fiala, A.: Monitorování a řízení procesů. [Online] [Cit: 20.202 .2018 . http://gps.fme.vutbr.cz/STAH_INFO/2512_Fiala_procesy.pdf

[3] Nenadál, J.: Příspěvek k měření a monitorování výkonnosti procesů v systémech managementu jakosti. [Online] [Cit: 20. 2. 2018.] http://katedry.fmmi.vsb.cz/639/qmag/mj24-cz.htm

[4] Flegl, R. Podnikové procesy a jejich spolehlivost. [Online] [Citace: 16.10 2018.] http://www.statspol.cz/cs/wpcontent/uploads/2013/05/request2006/sbornik/flegl.pdf

[5] Bícová, K.: Př́íspěvek k hodnocení ukazatelů výrobního procesu v oblasti automobilového průmyslu. Plzeň, 2016. Disertační práce. Západočeská univerzita v Plzni, Fakulta strojní.

[6] Töpfer, A. Six Sigma: koncepce a prŕíklady pro řízení bez chyb. Brno : Computer Press, 2008. ISBN: 978-802511766-8.

[7] Six Sigma Workshop. [Online] [Citace: 29. 6 2016.] http://www.slideshare.net/nandigama/six-sigma-workshopfor-world-bank-chennai-india

[8] Smajdorova, T., \& Noskievicova, D. (2017). Parametric versus nonparametric statistical process control. Paper presented at the Annals of DAAAM and Proceedings of the International DAAAM Symposium, 944-949. 